\title{
Hak wasiat anak dalam kandungan perspektif hukum Islam
}

\author{
Auliya Ghazna Nizami \\ Universitas Negeri Yogyakarta, Indonesia \\ Email: auliaghazna07@uny.ac.id
}

\begin{abstract}
Abstrak
Penelitian ini membahas tentang hak wasiat anak dalam kandungan dalam perspektif hukum Islam. Hukum Islam dalam hal ini adalah pendapat-pendapat para ahli fikih yang paling kuat dalam empat mazhab fikih yang paling dikenal. Menjadi sesuatu yang layak untuk dibahas dikarenakan masih kurangnya perhatian manusia dan tatanan hukum yang mengelilinginya terhadap hak wasiat anak dalam kandungan. Penelitian ini bertujuan untuk mengetahui bagaimana hukum Islam melindungi hak wasiat anak dalam kandungan dengan pendapat-pendapat terkuat yang ada. Penelitian ini berbentuk penelitian pustaka dengan cara mengumpulkan data dalam buku-buku fikih klasik untuk mengetahui pandangan dan pendapat para ahli fikih terdahulu dan artikel penunjang lainnya, bersifat yuridis normatif yang berusaha mengeluarkan nilainilai dan norma-norma dari pendapat-pendapat para ahli fikih klasik ataupun dalil-dalil yang termuat dalam hukum, dan menggunakan pendekatan deskriptif yang bertujuan untuk menggambarkan secara umum cakupan hukum Islam kaitannya dengan hak wasiat anak dalam kandungan. Penelitian terhadap hukum Islam ini menghasilkan pendapat terkuat dari setiap perdebatan internal dalam sebuah mazhab, dan pendapat terkuat dari kesemua mazhab atas sebuah kondisi wasiat anak dalam kandungan.
\end{abstract}

Kata Kunci : Anak Dalam Kandungan, Hukum Islam, Wasiat. 


\begin{abstract}
This study discusses the wașiya right of the fetus (janin) in the context of Islamic law. Islamic law in this regard is the opinion of the most powerful jurists in the four best known sects (mazhab). Being something that is worth mentioning is due to the lack of human attention and the legality that surrounds it to the rights of janin. This study aims to find out how Islamic law protects the rights of children in the content with the strongest opinions available. This research is a literature study by collecting data in classic jurisprudence books to find out the opinions and opinions of past jurists and other supporting articles, normative jurisprudence that seeks to extract values and norms from the opinions of classical jurists. or any of the arguments contained in the law, and uses a descriptive approach intended to illustrate in general the scope of Islamic law in relation to the rights of the janinn. This study of Islamic law produces the strongest opinions of any internal debate in a sect, and the most salient opinion of all mażhab on a wașiya right of the janin.
\end{abstract}

Keywords: Fetus, Islamic Law, Wașiya Right

\title{
Pendahuluan
}

Anak dalam kandungan atau sering disebut dengan janin adalah tahapan awal sebuah masyarakat. Dalam perspektif fikih atau definisi yang diberikan oleh Syafi'i bahwa istilah janin merupakan sebuah simbol dari proses akhir dari pembuahan sperma terhadap sel telur yang sebentar lagi akan lahir sebagai anak atau bayi dari kandungan ibunya, berbeda dengan Al-Nuwairi yang mengatakan bahwa yang disebut dengan janin jika sudah ditiupkan ruh (Mażkūr, 1996). Janin adalah amanah dari Allah yang harus dijaga sebagai generasi masa depan. Oleh karena itu janin harus tumbuh menjadi manusia seutuhnya. Untuk mencapai tahap ini diperlukan pemeliharaan dan perlindungan yang baik. Islam menggariskan agar pemeluknya menyiapkan generasi yang berkualitas dan untuk tidak mengkhawatirkan kesejahteraannya kelak Mażkūr, 1996).

Sangat disayangkan bahwa di Indonesia belum ada satu perundangundangan khusus yang mengatur akan perlindungan hukum terhadap janin secara menyeluruh. Dalam hukum positif yang berlaku di Indonesia, perlindungan terhadap janin hanya dipayungi oleh pasal-pasal yang sejatinya hanya mengatur perihal anak dan ibu hamil. Padahal pada kenyatannya, seiring dengan umur perkembangan janin hingga menjelang waktu kelahiran seharusnya janin memiliki perlindungan hukum yang beragam dan sesuai dengan umur 
perkembangannya. Selain itu, sebagaimana yang telah dijelaskan dalam kitab fikih klasik, janin memiliki efek yang berbeda di tiap umur perkembangannya terhadap hak-hak yang harus diterima ketika lahir ataupun terhadap hak-hak orang terdekatnya (al-Būqirī, 1990). Kekurangan payung hukum ini tentunya akan melahirkan celah dalam upaya memberikan perlindungan hukum terhadap janin, yang dapat berujung kepada tidak terpenuhinya hak-hak yang semestinya diterima oleh janin. Hal tersebut secara langsung maupun tidak langsung dapat membahayakan keselamatan janin bahkan dapat berdampak pada maraknya tindak pidana yang dialamatkan kepada janin maupun ibu hamil (Sudarto, 1986).

Upaya pemberian payung hukum yang spesifik terhadap janin, dengan mengusahakan pemberlakuan hukum Islam yang berkaitan dengan perlindungan janin harus ada diantaranya hukum yang jelas dan dapat dilaksanakan dengan baik oleh aparat penegak hukum maupun masyarakat (Arifin, 2001). Hal ini dikarenakan pengadilan di Indonesia selalu dan hanya bekerja berdasarkan undang-undang. Pengadilan sama sekali tidak boleh bekerja memberikan keadilan berdasarkan kebijaksanaan-kebijaksanaan atau rekomendasi-rekomendasi belaka (Arifin, 1996).

Undang- Undang Nomor 23 Tahun 2002 tentang Perlindungan Anak sebagai payung hukum utama untuk menyelamatkan anak dan hak-hak yang ada pada anak, haruslah selalu diperbaiki dan disempurnakan. Hal ini dikarenakan masih terdapat pelanggaran-pelanggaran yang luput dari cakupan payung hukum terhadap perlindungan anak dan hal tersebut sangat membahayakan bagi terjaminnya perlindungan terhadap hak anak. Janin yang sejatinya memiliki tingkat kebutuhan perlindungan lebih tinggi sangatlah beresiko apabila hanya dipayungi oleh UU Perlindungan Anak tersebut (Tanamas, 1999). Perlindungan terhadap janin hanya bisa terwujud apabila ada hukum yang manaunginya karena hukum adalah kekuatan yang mengatur, menguasai, dan sekaligus melindungi (Rahardjo, 2000). Berkenaan dengan peran hukum tersebut, kekuasaan yang dimiliki oleh hukum melekat pada Tuhan, manusia dan pada organisasi masyarakat, yakni negara.

Payung hukum dari dimensi hukum Islam dapat diwujudkan dengan cara transformasi asas dan kaidah hukum Islam ke dalam peraturan perundangundangan. Khusus di Indonesia, peran hukum yang berkuasa untuk mengatur dan mengikat dari hukum Islam tersebut tersebar dalam berbagai aturan perundang-undangan, baik dalam hukum pidana, hukum keluarga, maupun hukum keperdataan lainnya (Ka’bah, 2013). 
Berangkat dari pemaparan di atas, dalam penelitian ini peneliti menggali dan mengkaji lebih mendalam mengenai aspek perlindungan hukum terhadap janin kaitannya dengan hak wasiat yang telah digariskan dalam peraturanperaturan dalam kitab-kitab fikih klasik dan kontemporer.

\section{Metode}

Penelitian ini berbentuk penelitian pustaka dengan cara mengumpulkan data dalam buku-buku fikih klasik untuk mengetahui pandangan dan pendapat para ahli fikih terdahulu dan artikel penunjang lainnya, bersifat yuridis normatif yang berusaha mengeluarkan nilai-nilai dan norma-norma dari pendapat-pendapat para ahli fikih klasik ataupun dalil-dalil yang termuat dalam hukum, dan menggunakan pendekatan deskriptif yang bertujuan untuk menggambarkan secara umum cakupan hukum Islam kaitannya dengan hak wasiat anak dalam kandungan.

Penelitian terhadap hukum Islam ini menghasilkan pendapat terkuat dari setiap perdebatan internal dalam sebuah mazhab, dan pendapat terkuat dari kesemua mazhab atas sebuah proses pewasiatan kepada anak dalam kandungan. Di antara hal-hal yang diperdebatkan dan akan dibahas dalam penelitian ini adalah perdebatan para hali fikih dalam syarat-syarat yang harus dipenuhi anak dalam kandungan untuk dapat memperoleh hak wasiat yang dialamatkan kepadanya, batas bawah dan batas atas usia kehamilan, dan bentukbentuk pewasiatan terhadap anak dalam kandungan lainnya.

\section{Hasil dan Pembahasan}

\section{Pengertian Wasiat}

Wasiat adalah salah satu bagian dari hukum waris. Berwasiat adalah salah satu cara dalam ilmu waris untuk memberikan harta peninggalan kepada ahli waris ataupun yang bukan ahli waris. Meski begitu, banyak pendapat dalam hukum Islam (fikih) yang mengatakan bahwa ahli waris tidak sah untuk mendapatkan wasiat. Agar tidak terjadi praktek ketidak-adilan di antara para ahli waris dan yang bersangkutan lainnya dalam hal berwasiat, Islam memberikan batas atas harta yang boleh diwasiatkan kepada seorang individu, yaitu sepertiga dari keseluruhan harta.

Janin, dalam pembahasan bab waris, berhak dan sah untuk mendapatkan warisan meskipun belum dilahirkan. Wasiat sebagai salah satu hak yang diatur 
dalam hal pewarisan, adalah hak yang sah diterima oleh janin meski janin tersebut belum dilahirkan. Sebelum menjelaskan lebih lanjut tentang hak janin dalam wasiat dan posisinya dalam suatu proses pewasiatan, akan dijelaskan terlebih dahulu beberapa hal yang berkaitan dengan wasiat.

Pengertian wasiat secara bahasa: secara bahasa wasiat berasal dari kata wașaya, jika dikatakan awșaitu aḥmada mālan atau "aku wasiatkan kepada Ahmad sejumlah harta", berarti aku jadikan sejumlah harta itu milik Ahmad.

Pengertian wasiat dalam syara': dalam hal ini tiap golongan memiliki pendapat yang berbeda, yaitu: Hanafiyyah: wasiat adalah istilah untuk sesuatu yang diberikan oleh si mati setelah kematiannya (al-Kāsāni, 1986).

Mālikiyyah: mereka berpendapat bahwa wasiat memiliki definisi yang berbeda di antara kalangan ulama fikih dan ulama ilmu waris. Mereka melihat bahwa ulama fikih memiliki definisi yang lebih umum terhadap wasiat, sedangkan para ulama ilmu waris mendefinisikan wasiat hanya terbatas pada sepertiga harta warisan yang akan diwasiatkan. Dengan begitu, para ulama Mālikiyyah mendefinisikan wasiat sebagai sebuah akad yang mengakibatkan adanya pemindahan hak sebesar sepertiga dari jumlah harta warisan yang ditinggalkan oleh pewaris setelah kematiannya(ad-Dasūqi, n.d.).

Syāfi'iyyah: wasiat adalah pemberian atau penghibahan sebuah hak setelah adanya kematian seseorang (al-Qalyūbi, 1995). Hanābilah: wasiat adalah sebuah kejadian transaksional yang terjadi setelah adanya kematian (al-Hanbali, n.d.). Dan sebagian yang lain dari mereka mendefinisikan wasiat dengan sebuah kepemilikan yang ditangguhkan setelah adanya kematian seseorang, yaitu dengan cara hibah harta, harta bisa berupa benda, manfaat, atau hutang ('Ābidīn, 1992a).

\section{Dasar Hukum Wasiat}

Diberlakukannya wasiat dalam syariat Islam berdasarkan beberapa dalil, baik itu dari Alquran maupun Hadis, yaitu: Alquran, surat al-Baqarah (2: 180):

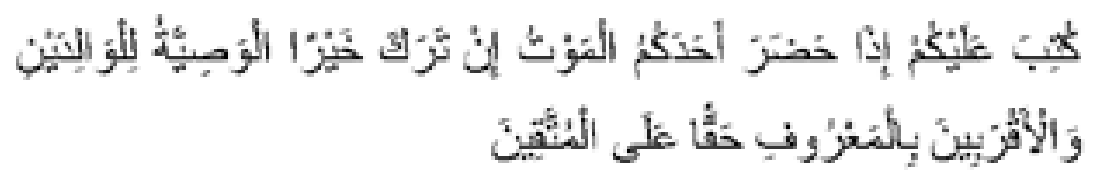

Diwajibkan atas kamu apabila seseorang di antara kamu menemui ajal dan meninggalkan harta (yang baik), maka hendaklah berwasiat untuk orangtua dan kerabat dengan cara yang baik (ma'rüf) karena yang seperti adalah hak bagi 
Hadis:

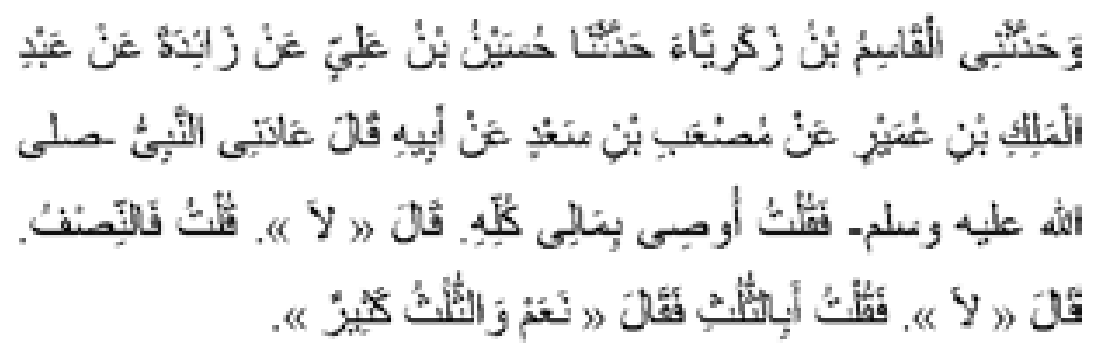

Diriwayatkan dari Qasim bin Zakariyyā diriwayatkan dari Husain bin 'Ali dari Zaidah dari 'Abdil Malik bin 'Umair dari Muṣ'ab bin Sa'ad dari bapaknya berkata; Rasulullah berkunjung kepadaku dan aku berkata, 'aku berwasiat dengan semua hartaku'. Rasulullah berkata; "tidak", aku berkata, 'setengahnya', Rasulullah berkata, "tidak”, dan aku berkata, 'apakah dengan sepertiga?', Rasulullah berkata, "Iya, sepertiga sudahlah cukup"(Muslim bin Hujjāj, n.d.).

Ijma $\bar{a}$ (kesepakatan ulama dan pakar)

Para ulama bersepakat bahwa wasiat telah diberlakukan secara sah dalam hukum Islam. Kesepakatan ini seperti yang tertuang dalam badai'u aș-șanā' '’ fī tartīb sy-syarā' 'i' yang menjelaskan bahwa umat Islam sejak zaman Rasulullah sampai saat ini saling berwasiat tanpa ada penolakan dari siapapun(al-Kāsāni, 1986).

'Aqliy (dasar hukum logis)

Setiap individu manusia mendambakan akhir waktunya di dunia dengan senantiasa dalam usaha mendekatkan diri kepada Sang Pencipta. Dengan adanya hadis yang menyebutkan pemberlakuan wasiat yang sah, baik kiranya seseorang sebelum ajal menjemputnya, meninggalkan wasiat yang baik kepada yang ditinggalkannya. Syariat Islam memberlakukan wasiat karena kebutuhan umat manusia akan sesuatu yang baik untuk dilakukan sesaat sebelum ajal menjemput, begitu juga sebagai sarana pemindahan kepemilikan yang sah dari harta yang dimiliki oleh si mati kepada para ahli warisnya atau orang yang di luar ahli waris yang hendak dihibahkan wasiat untuknya.

Termasuk salah satu bentuk kasih sayang Allah kepada manusia adalah dengan adanya amalan-amalan sunnah yang menjadikan suatu ibadah menjadi lengkap. Wasiat sebagai suatu amalan yang sunnah dapat menjadi pelengkap tujuan awal manusia diciptakan, yaitu untuk beribadah. Disebutkan dalam satu riwayat; 


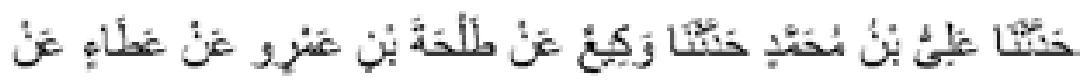

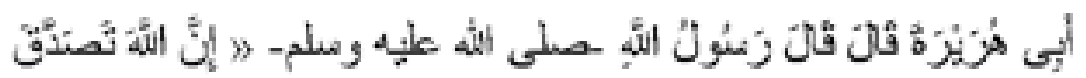

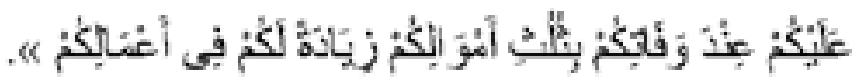

Diriwayatkan oleh 'Ali bin Muhammad dari Wāqi' dari Talhah bin 'Amr dari 'Ața' dari Abī Hurairah berkata, Rasulullah berkata, "sesungguhnya Allah bersedekah kepadamu dengan sepertiga hartamu (wasiat), agar menjadi tambahan kebaikan untukmu".

Wasiat memiliki batasan-batasan yang membuatnya tidak selalu dalam satu hukum saja, dengan kata lain, wasiat tidak selalu menjadi amalan sunnah, wasiat bisa menjadi makrūh apabila si meninggal meninggalkan sedikit harta dan para ahli waris sangat membutuhkan harta warisan tersebut, bahkan wasiat bisa menjadi haram apabila dengan berwasiat dapat membahayakan para ahli waris.

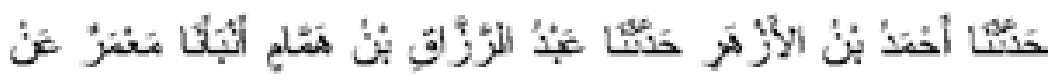

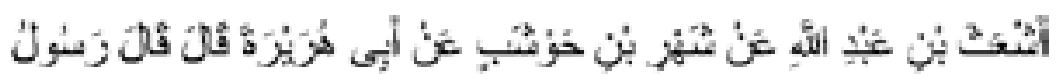

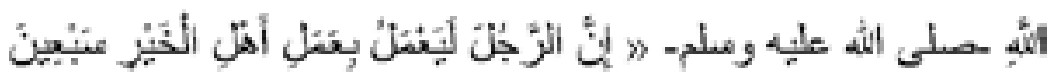

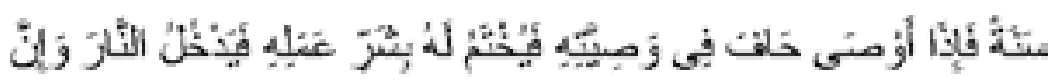

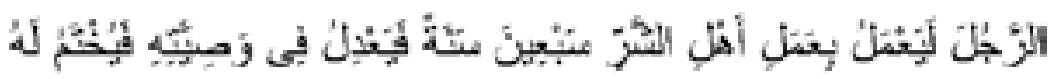

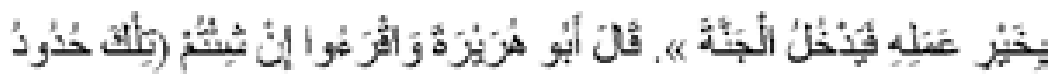

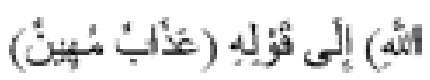

Diriwayatkan oleh Ahmad bin Azhar dari 'Abdu arrazzāq bin Hammām, diberitahukan kepada kami oleh Ma'mar bin Asy'as bin Abdillah dari Syahr bin Hausyab dari Abī Hurairah berkata, Rasulullah berkata, "sesungguhnya seseorang telah mengerjakan amalan kebaikan selama tujuh puluh (70) tahun, kemudian ia berwasiat dengan niat mencelakakan, maka ia menutup amalan baiknya itu dengan satu amalan yang buruk yang menjerumuskannya ke dalam 
api neraka. Dan sesungguhnya seseorang telah mengerjakan amalan buruk selama tujuh puluh (70) tahun kemudian ia berwasiat dengan cara yang baik dan adil, maka ia menutup amalan-amalannya dengan amalan yang baik dan ia berhak untuk masuk surga. Abu hurairah berkata, bacalah jika kamu berkenan ayat tilka hudūdullahi hingga 'ażābun muhīnun.

\section{Perlindungan Hukum Terhadap Hak Wasiat Terhadap Janin}

Para ahli fikih klasik tidak berselisih pendapat tentang keabsahan wasiat terhadap anak dalam kandungan, meski begitu terdapat beberapa syarat yang harus dipenuhi dan para ulama satu dengan yang lainnya saling memberikan pandangannya dalam setiap syarat yang harus dipenuhi, sebagaimana yang akan dijelaskan berikut ini:

Kepastian nasab janin. Harus disahkan secara hukum bahwa janin tersambung nasabnya kepada bapaknya. Hal ini dikarenakan, apabila nasab janin terhalang oleh satu hal seperti li'ān, maka tidak diperbolehkan kepada janin tersebut.

Seperti yang disebutkan dalam al-Mugni, apabila diwasiatkan kepada anak dalam kandungan seorang perempuan dengan suaminya atau tuannya (apabila perempuan tersebut seorang hamba sahaya), maka wasiat tersebut sah untuk dilakukan dengan syarat kepastian nasab anak tersebut, apabila nasabnya terhalang oleh li'ān maka wasiat tidak sah dilakukan karena kepastian nasab yang disyaratkan tidak terpenuhi (Qudāmah, 1968).

Kepastian keberadaan janin. Ulama Syāfi'iyyah dan Hanābilah mensyaratkan kepastian keberadaan janin ketika dilangsungkannya wasiat, dan sebagian lain menyaratkannya ketika kematian yang memberi wasiat. Hal ini berkaitan dengan batas bawah dan batas atas umur kehamilan (an-Nawawi, n.d.).

Para ulama Hanafiyyah, Syāfi'iyyah, dan Hanābilah berpendapat bahwa apabila kehamilan berlangsung kurang dari jangka waktu enam bulan dari berlangsungnya wasiat, baik masih dalam hubungan perkawinan atau tidak, maka janin tersebut berhak untuk mendapatkan hak wasiat.

Apabila janin dilahirkan dalam jangka waktu enam bulan, dan masih dalam hubungan perkawinan, maka janin tidak berhak atas wasiat, dikarenakan adanya kemungkinan awal kehamilan terjadi setelah wasiat berlangsung, sedangkan apabila terlahir dalam jangka waktu enam bulan dan tidak dalam hubungan perkawinan, maka janin berhak atas wasiat('Ābidīn, 1992). 
Dalam batas atas umur kehamilan yang dapat diberikan wasiat ada dua pendapat yang berbeda, yaitu: Hanafiyyah, Apabila seorang ibu mengandung janin kurang dari dua tahun, dan tidak dalam satu hubungan perkawinan, maka janin tersebut berhak atas wasiat(al-Kāsāni, 1986).

Syäfi'iyyah, pendapat paling terkenal di kalangan ulama Syäfi'iyyah dan satu pendapat lain dari kalangan Hanābilah bahwa seorang perempuan apabila mengandung janin kurang dari jangka waktu empat tahun, dan ia tidak dalam hubungan perkawinan, maka janin tersebut berhak atas wasiat(asy-Syarbīnī, n.d.).

Ulama dari kalangan Mālikiyyah tidak memberikan syarat apapun dalam pewasiatan kepada janin. Mereka berpendapat bahwa wasiat dapat diberikan kepada janin yang telah ada atau janin yang belum ada. Apabila seseorang berkata, "saya berwasiat kepada anak yang akan lahir dari Zaid", dimana anak tersebut tidak ada ketika wasiat berlangsung, maka harta yang diwasiatkan ditangguhkan hingga kelahiran janin tersebut. Jika janin terlahir dalam keadaan mati, maka harta wasiat tersebut dikembalikan kepada para ahli waris yang berwasiat.

Syäfi'iyyah di salah satu pendapatnya sepakat dengan pendapat Mālikiyyah yang menyebutkan bahwa wasiat boleh diberikan kepada janin yang belum ada, dikarenakan sesuatu yang belum ada diperbolehkan untuk memiliki sesuatu, seperti yang terjadi dalam praktek salam muajjal. Barang yang diperjual-belikan dalam salam muajjal tidak disyaratkan keberadaannya ketika akad dilangsungkan. Seperti halnya diperbolehkan berwasiat dengan harta yang belum ada, contohnya, berwasiat dengan buah yang baru akan muncul di kemudian hari. Dalam praktek pewasiatan kepada janin yang belum ada, Syāfi'iyyah mensyaratkan beberapa hal, yaitu;

Janin dilahirkan lebih dari jangka waktu empat tahun, juga di antara enam bulan hingga empat tahun dan sang ibu dalam suatu hubungan perkawinan yang memungkinkan kehamilan terjadi akibat hubungan perkawinan tersebut (asy-Sylfi'i, n.d.); Janin dilahirkan dalam keadaan hidup, jika dilahirkan dalam keadaan mati, maka tidak ada perbedaan pendapat di antara ulama akan batalnya wasiat terhadap janin tersebut.

\section{Bentuk-bentuk Wasiat terhadap Anak dalam Kandungan}

Apabila lahir dua anak kembar di dua waktu yang berbeda. Dalam hal ini terdapat dua pendapat yang berbeda, yaitu: Pendapat pertama, pendapat 
yang mengatakan bahwa bagian kedua anak kembar tersebut berbeda, yaitu golongan Hanafiyyah dan Syāfi'iyyah.

Hanafiyyah berpendapat apabila seseorang berkata, "apabila di dalam kandungan seorang ibu ada seorang anak perempuan maka baginya seribu, dan apabila di dalamnya anak laki-laki maka baginya dua ribu", kemudian terlahir seorang anak perempuan dengan umur kandungan enam bulan kurang satu atau dua hari, dan terlahir anak laki-laki berselang dua hari setelahnya. Maka bagi kedua anak kembar tersebut wasiat si meninggal, karena mereka berdua tercipta dari satu asal (air mani) yang sama, dan keberadaan mereka telah sah secara hukum dikarenakan salah satu dari keduanya terlahir sebelum genap enam bulan setelah kematian si pewasiat(al-Kāsāni, 1986).

Syāfi'iyyah berpendapat bahwa kelahiran salah satu di antara kedua anak kembar sebelum jangka waktu enam bulan dan satu lainnya terlahir setelah jangka waktu enam bulan tidak menghalangi keduanya dari mendapatkan wasiat, baik sang ibu dalam satu hubungan perkawinan atau tidak(asy-Syarb】n】, 1994).

Pendapat kedua, yaitu pendapat yang tidak mempermasalahkan perbedaan waktu kelahiran dua anak kembar, karena keduanya adalah satu masa kandungan yang sama. Hal ini diungkapkan oleh para Hanābilah (alHanbali, n.d.).

Apabila dikatakan; "apabila di kandungan seorang perempuan ada anak perempuan maka baginya seribu dari harta warisan, apabila laki-laki maka baginya dua ribu dari harta warisan" dan terlahir dua anak laki-laki atau dua anak perempuan.

Dalam masalah ini terdapat dua pendapat yang berbeda, yaitu: Pendapat yang mengatakan bahwa wasiat batal. Pendapat ini diungkapkan oleh Hanafiyyah, yang mendasari pendapat mereka dengan masalah yang lain, yaitu apabila seseorang berwasiat dengan sepertiga hartanya kepada salah satu di antara dua orang laki-laki, atau kepada fulan dan fulan, maka wasiat dianggap batal, begitu juga dengan wasiat dalam masalah ini (al-Kāsāni, 1986).

Pendapat yang mengatakan bahwa wasiat dapat dilaksanakan. Hanafiyyah mengungkapkan bahwa wasiat sah bagi kedua anak yang dilahirkan, bagian sesuai dengan yang disebutkan oleh si pewasiat(asy-Syāfi'ī, 1990).

Pendapat lain dalam Hanafiyyah menyebutkan bahwa wasiat dapat diberikan kepada anak kembar yang dilahirkan dengan syarat ketentuan bagian wasiatnya ditentukan oleh ahli waris lainnya, dikarenakan ketidak-tahuan si 
pewasiat akan kondisi kelahiran anak kembar.

Ulama lain tidak mempermasalahkan perbedaan isi wasiat dengan kondisi kelahiran, karena akad wasiat disini berkaitan dengan semua yang ada di dalam kandungan, terlepas dari jenis kelamin dan jumlah yang sebenarnya (al-Kāsāni, 1986).

Apabila dikatakan; "apabila yang di dalam kandungan seorang perempuan atau apabila seorang perempuan mengandung anak laki-laki maka baginya sekian, jika mengandung anak perempuan maka baginya sekian lain.”

Jika dikatakan demikian dalam sebuah wasiat, kemudian terlahir satu anak laki-laki dan satu anak perempuan maka tidak bagi keduanya hak wasiat, dikarenakan lafal wasiat mencakup semua yang di dalam kandungan, dan satu anak laki-laki tidak berarti anak perempuan yang juga ada di dalam kandungan.

Menurut Hanafiyyah dan Hanābilah, perbedaan antara masalah pertama dan kedua adalah, dalam masalah pertama tidak ada syarat detail obyek wasiat, dari segi jenis kelamin atau jumlah. Di masalah pertama hanya disyaratkan di dalam kandungan anak laki-laki atau anak perempuan. Sehingga yang mempengaruhi dari lafal wasiat hanyalah jumlah bagian yang ditetapkan untuk tiap anak laki-laki atau anak perempuan(as-Sarkhasyi, 1993).

Bentuk Ketiga: apabila dilahirkan dua anak, yang satu terlahir dalam keadaan hidup dan satu lainnya terlahir dalam keadaan mati. Maka dalam masalah ini, wasiat semuanya jatuh kepada anak yang terlahir dalam keadaan hidup. Karena belum diketahui kelangsungan hidup sang anak yang mati setelah meninggalnya si pewasiat. Hal ini sama saja apabila seseorang berwasiat kepada satu orang yang hidup dan satu orang lainnya mati, maka wasiat semua jatuh kepada orang yang hidup, karena orang mati tidak termasuk ahli waris, dan wasiat adalah bagian dari waris. Masalah ini berbeda halnya dengan apabila terlahir dua anak dalam keadaan hidup, tidak lama berselang setelah kelahirannya dalam keadaan hidup anak tersebut mati, maka wasiat itu hak anak yang mati tersebut yang kemudian dipindahkan kepemilikannya kepada ahli warisnya (as-Sarkhasyi, 1993).

Bentuk Keempat: "apabila berwasiat kepada kandungan seorang perempuan, kemudian terlahir lebih dari satu anak.” Terlahir dua orang anak, satu laki-laki dan satu perempuan, maka bagi keduanya wasiat dengan bagian yang sama, karena wasiat adalah pemberian atu hibah. Bagian akan berbeda apabila disebutkan dalam lafal wasiat dari si pewasiat (ad-Dardīr, n.d.). 
Humanika, Kajian IImiah Mata Kuliah Umum, Vol. 20. No. 1. (2020), 31-44

\section{Kesimpulan}

Perspektif hukum Islam, menjamin hak waris anak dalam kandungan. Ketentuan besaran hak waris tergantung dengan syarat-syarat yang dipenuhi sang anak dan kondisi-kondisi kelahirannya. Masih banyak ruang dalam diskursus anak dalam kandungan yang masih belum dibahas dan menjadi diskusi keilmuan, terutama dalam kajian multidisiplin pendekatan ilmu. Semoga kajian selanjutnya dapat mengurai dengan multidisiplin ilmu sehingga hak-hak anak semakin mendapat tempat dalam berbagai kajian ilmiah. Wallāhu a'lam bis șawāb.

\section{Daftar Pustaka}

'Ābidīn, I. (1992a). Radd al-Mukhtār 'alā ad-Durr al-Mukhtārr. Dār al-Fikr.

'Ābid̄̄n, I. (1992b). Radd al-Mukhtāor 'alā ad-Durr al-Mukhtār. Dār al-Fikr.

Abdullah bin Hijāzi bin Ibrāhīm asy-Syāfi'i. (n.d.). Hāsyiyatu asy-Syarqāawi. Mațba'atu al-Amīriyyah.

Abū Bakr bin Mas'ūd bin Aḥmad al-Kāsāni. (1986). badāiu' aṣ-șanāi' fī Tartīb asy-Syarāi'. Dār al-Kutub al-'Ilmiyyah.

Aḥmad bin Muḥammad bin Aḥmad ad-Dardīr. (n.d.). asy-Syarḥu aṣ-ṣagīr alā aqrabi al-masāliki ilā mażhabi al-Imām Mālik. Dār al-Ma'ārif.

Ahmad Salāmah al-Qalyūbi, A. al-B. (1995). Hāssyiyatu Qalyūbi wa 'Umairah. Dār al-Fikr.

Arifin, B. (1996). Pelembagaan Hukum Islam di Indonesia: Akar Sejarah, Hambatan dan Prospeknya. Gema Insani Press.

Awātẹef Tahsīn Abdillah al Būqirī. (1990). Ahkāmul Janīn waț Tifl fī al Fiqh al Islāmiy. Umm Qurrā' University.

Arifin, B. (2001). Kompilasi Hukum Islam di Indonesia.: Direktorat Pembinaan Badan Peradilan Agama Islam, Direktorat jenderal Pembinaan Kelembagaan Agama Islam Departemen Agama Islam R.I.

Ibnu Qudāmah. (1968). al-Mugnī. Maktabatu al-Qāhirah.

Manșūr bin Yūnus bin Ṣalāḥ ad-dīn bin Idrīs al-Hanbali. (n.d.). Syarḥu Muntahā al-Irāà̄t. 'Ālam al-Kutub.

Muḥammad bin Aḥmad bin 'Arafah ad-Dasūqi. (n.d.). Hāsyiyatu ad-Dasūqi alā asy-syarhi al-kabīr. Dār al-Fikr.

Muhammad bin Ahmad bin Abū Sahl as-Sarkhasyi. (1993). al-Mabsūṭ. Dār al- 
Ma'rifah.

Muḥammad bin Idrīs asy-Syāfi'̄̄. (1990). al-Umm. Dār al-Ma'rifat.

Muhammad Salam Mażkūr. (1996). al Janīn wal Ahkām al Muta'alliqah bihi fī Fiqhil Islām. Dārun Nahụah al Arabiyya.

Muhȳ̄ ad-Dīn Yahyā bin Syaraf an-Nawawi. (n.d.). al-Majmū' Syarḥ al-Muhażżab. Dār al-Fikr.

Muslim bin Hujjāj. (n.d.). Șah̄ih Imām Muslim. Dār Ihyā at-Turāì al-'Arabi.

Rifyal Ka'bah. (2013). Peraturan Perundang-undangan Islam di Indonesia. Wordpress. dakwah.wordpress.com/2013/08/21/Peraturan-perundang-undanganislam-di-indonesia

Satcipto Rahardjo. (2000). Ilmu Hukum. Citra Aditya Bakti.

Sudarto. (1986). Hukum dan Hukum Pidana. Alumni.

Syamsu ad-Dīn asy-Syarbīnī. (n.d.). al-Iqnā' fī ḥilli alfāżi Abī Syujā'. Dār al-Fikr.

Syamsu ad-Dīn asy-Syarbīnī. (1994). Mugnī al-Muḥtāj ilā Ma'rifati Ma'ānī Alfāżi al-Minhāj. Dār al-Kutub al'Ilmiyyah.

Tanamas, M. J. dan Z. Z. (1999). Aspek Hukum Perlindungan Anak dalam Perspektif Konvensi Hak Anak. Citra Aditya Bakti. 
Humanika, Kajian IImiah Mata Kuliah Umum, Vol. 20. No. 1. (2020), 31-44 